\title{
PSYCHOLINGUISTIC PECULIARITIES FOR APPLICATION OF THE SYMBOL- WORDS IN THE POLITICAL COMMUNICATION
}

\author{
Yuliya Krylova-Grek \\ State University of Telecommunications, Kyiv, Ukraine \\ doca123@ukr.net
}

\begin{abstract}
The article deals with the language semantic units and peculiarities of their performance from the point of view of linguistics. The author highlights how the semantic unit application in a certain function (name-word or symbol-word) influences the speech efficiency of the politician supplementing his/her political image. We investigated a symbol-word as a semantic unit with inherent psychological and linguistic features which lie in the fact that the properties of the object are manifested; its main and additional meaning as well as feelings are expressed through the language means. By segregating the differences of the symbol-word from other semantic units we defined its main functions in the political speech that make it possible for the text to turn into a powerful tool of influence on the listener's consciousness. Due to the analysis of the words in the function of respective semantic units we were able to realise certain mechanics of the impact on the recipient's (public) consciousness and to assess their role in the efficiency of emphasis in the speech and the possibility of getting an emotional response from the listener. We defined the aspects enabling the political speech to increase influence on the audience. Firstly, the use of symbol-words in the speech of a politician makes it possible to build the speech addressed not to the rational thinking but affects an unconsciousness suggesting stable meanings. Secondly, with the help of symbols the most vulnerable fields of consciousness are affected, which in turn can trigger strong emotions (fear, anxiety, hope, etc.). Based on the analysis of the speech by Donald Trump, we demonstrated how the change of semantic unit function from the name word to the symbol-word is capable of distinguishing emphasis that increases the efficiency of influence on the public consciousness.
\end{abstract}

Keywords: symbol-words; political speech; semantic units; psycholinguistic peculiarities; efficiency; influence; audience.

\section{Introduction}

During the last decades considering modern social and political processes the communication in political field attracts close attention of both the scientists and the society in general. A large number of various political talk shows on TV and forecasts of political experts are not losing their popularity. Such attention to political life is not a coincidence: politics influences the major spheres of our life from economics on out to education.

The relevance of the study is predetermined by the substitution of critical discourse and rational analysis of the modern political communication. The critical thinking is substituted for external performance. We observe the so-called "transformation of the political" by means of "expulsion of the political" (Meyer, 1994, p. 130).

The political discourse issues were covered from the point of view of various humanitarian sciences, for example, in the works in political science the political discourse was viewed by Nagorna (2005), Akinchyts (2007), van Dijk (2013), Potcheptsov (2006), Rotar (2015), Shomova (2016) and others. In the field of philosophy, the role of symbol was highlighted within the frames of the conception of symbolic politics with the focus on the symbols as an integral part of a myth, non-verbal symbols, and rituals (Eidelman, 1990; Sartsinelli, 2011; Mayer, 1994; Potseluev, 2014; Malinova, 2015 etc.). The issues of the political leader image were studied by Pocheptsov (1997), Bird (1999), Segela (1999), Davydova (2006) and others. The methods of analysis of communication were studied by Ukrainian scientists Ivanov (2004) and Pocheptsov (2015). At the same time, the problem of the role of the language and speech as a tool of influence on the consciousness in the political discourse was not subject to profound investigation. Neither was the mentioned problem subject to inter-industry investigation, which is quite an urgent matter in the modern science.

Thus, the analysis of literary sources revealed that from the point of view of psycholinguistics the issue of political communication was not investigated. This is what predetermines the urgency of the analysis of the political sphere of the language and speech from the point of view of psycholinguistic aspects, in particular: the role of semantic units (symbol-words) in the communication between the definite persons involved in the political life and the public. It is practicable in psycholinguistics to distinguish the semantic units' functions as follows: verbal name "name-word", verbal notion "notion-word", and verbal symbol "symbol-word" (Krylova-Grek, 2007). In the present work we would like to investigate the role of symbolwords in political communication. 
The aim of the article is to analyse the semantic units in the political discourse, to determine the functions of the word-symbol in the political communication and demonstrate its capability to influence on the efficiency of the speech.

This study demonstrates how the change of the semantic unit function from the name-word to the symbol-word is capable of influencing the consciousness of the audience. It is also important by means of psycholinguistic approach to highlight how the application of semantic units in different functions effects the organisation of the speech of the politician and supports his/her political image.

\section{Methods}

According to the aim of the present work, we applied such general scientific methods as data collection, study of the works in allied disciplines on the problem of research, analysis of the text semantic units, intent analysis, and the semantic differential method. The mentioned methods were developed, approbated, and made it possible to obtain valid data. A practical analysis of the functional meaning of symbol-words was carried out based on the extract from an interview of Donald Trump during his pre-election campaigning and provides a vivid example of how symbol-words are able to influence the mainstream audience.

\section{Results and Discussion}

The functions of symbol-words in the political speech

They distinguish several directions in the study of the process of the language generation and perception. One of these is the issue of the influence of speech on the addressee's consciousness. An undeniable fact is that all the elements in the process of perception and generation of speech are extremely important. Each sound forming a word, each word acting as this or that semantic unit and building the sentence, all this forms a unified algorithm creating a system that is realised in the form of a written or oral text. It is common knowledge that the intonation, place and semantic meaning of each element of the speech can in this or that way influence the addressee's consciousness. It should be mentioned that the power of this influence also depends on the way the semantic units of the text are applied.

It is practicable in psycholinguistics to divide the semantic units into three categories: name words, notion words, and symbol-words. The analysis of the words in the function of respective semantic units enabled us to understand certain mechanisms of influence the recipient's (public) consciousness and to assess their role in the efficiency of accentuation in the speech and the possibility to get the listener's emotional response. In this article, we are going to analyse the influence of the function change of a semantic unit in a political speech, in particular, of a name word into a symbol-word on its successful perception by the listeners (Krylova-Grek, 2007).

Based on the intent analysis approach we distinguished the symbol-words in the political speech:

- the function of accentuation;

- the function of emotional involvement;

- the function of narrowing of the symbol-word semantic field.

One can state without exaggeration that the politician's speech is a part of his/her political advertising campaign with the text being to some extent a merchandise suggesting images and ideas and is intended to "increase the value" or, in other words, to increase the popularity of the speaker as such.

In order to analyse the speech products from the point of view of psycholinguistics we paid our attention to the semantic units in the text, analysed their functional role and obtained the results demonstrating how the application of the same semantic unit in different functions (in the role of the notion word or of the symbol-word) influence the political text efficiency and its sense.

\section{The function of symbol-words in political communication}

1. The function of accentuation.

Any political communication is characterised by the use of certain speech structures, which are aimed at attracting attention to certain details that we call accents. In order to reach the goal the speech has to be built in a certain sequence and acquire the features of a logical message, in which the ideas that have to attract the most attention are put into the forefront.

Due to the change of function of the semantic unit the speech gets so vivid emphasis/accents that the remaining words turn into a background. The application of the mentioned accents is a tool that is able to evoke bright memories or associations related not only to the public but also personal interests.

2. The function of emotional involvement.

The aspects of an emotional part include referring to inherent fears, hopes and receiving an emotional response depending on the certain situation (irrespective of the fact whether we speak of an individual, a team or a society in general). 
For example, if in the context of general problems we speak of "we" in the sense of "the people" this creates an illusion of unity with an emphasis on the thought: "all that is beneficial for "us" is beneficial for me". Such a trick for the application of a semantic unit usually arises a lively emotional response in the public. Another example is as follows: the notion word "bill" when used in a political context of a present economic situation acquires the function of a symbol-word meaning "misery, impoverishment and total belttightening" which in its turn triggers strong emotions arising the feelings of complete social injustice. In the result, the politician's speech becomes brighter and gets the listeners' emotional response, gets the chance to supplement a chosen political image and to increase the circle of potential voters.

3. The function of narrowing of the symbol-word semantic field.

An artificial transfer of the meaning of the name word to the symbol-word and further limitation of its semantic meaning cuts off the correlation and generalisation of an endless range of manifestations of the object or phenomenon. This, in its turn, results in the narrowing of the semantic field of the symbol-word and makes it possible to concentrate on a rather limited scope of problems, which has an intention to underline one features and to neglect the other, that are in fact no less important. As an example we would like to provide a rather widely spread speech behaviour, when in public speeches the name-word of religious belonging "a Muslim" is turned into a symbol-word of terrorism. Thus, the subjective apperception of certain layers of society is being speculated upon.

Exercising a psychological influence and introducing the changes into the public consciousness through a political speech is a sophisticated process requiring a thorough preparation and weighing the meaning of each word.

It should be emphasised that the same fact or phenomenon is differentially perceived by different people depending on subjective factors. One of the key parts here is played by the subjective apperception of perception of one and the same word. There is an opinion that the apperception depends on individual, national and psychological peculiarities of the person. Moreover, the apperception can be traced everywhere the perception is supplemented and explained by the reserve of individual psychics mechanisms (feelings, imagination, perception, etc.).

\section{The symbol-words in the political discourse}

In the political communication the symbols are used as main means addressing the unconscious collective (analogue to the archetypes and myths). It is the unconscious collective, according to Jung (2015; 2016) that is a basis of symbolic images, including also the verbal symbols which we name as "symbolwords".

The language genres influence the functional role of the semantic units when building a coherent utterance. It is only within an utterance, where the word is subject to analysis as a text semantic unit. It should be mentioned that the words are completely identical by the form but have a different semantic content and function, what can be discovered only in a specific real life situation.

The symbol-word is characterised by both psychological and linguistic features: it reflects the features of an object, its main and supplementary meanings, and feelings. An image contains implicit information, which represents a transition link between the feeling and the thought.

Based on the conception of symbol by Losev (2014), five criteria of the symbol were defined by us, which disclose its general semantic structure and distinguish from other semantic units.

1) The symbol is not the contents of its object, it constructs and generates initial models and images; 2) the symbol of an object is already its generalisation; the generalisation already existing in the symbol already contains in itself everything what it symbolises, even if it were endless; 3 ) the symbol of an object is its internal and external expression organised according to the general construction principles, which we call a language appearance; 4) the symbol of an object is its structure containing an end or endless range of single manifestations of this structure; 5) the symbol of an object is an identity, interpenetration of an object and its imagery designating it. This symbolic identity is an integrity preconditioned by this or that unified principle, which generates it and turns it into an end or endless range of different naturally obtained units, which merge into a total identity of the principle or model that were in their basis.

Thus, symbol-words in the political speech strengthen the influence on the audience and outline the four aspects as follows:

1. The conceptual importance of the text or expression of the ideas meeting the expectations of the society: "to let to hear what is wanted to be heard";

2. Distinctive character of the text, which has to ensure a unique nature and recognisabity of the speaker among the rest; 
3. Emotional influence, i.e. the stronger emotions the speech provokes, the more are the chances for success, and in the case of the pre-election campaign the more is the likelihood of supporting the candidate as "our" (i.e. the one who is concerned with the same problems as the majority of addressees have);

4. Encouragement and consent, i.e. the aspect that we call the "boa Kaa" tactics, meaning the arguments strengthened by symbol-words, which arise in such order and sequence that no negation is provoked but rather understanding and consent with every message.

As it is clear from the mentioned above, the usage of the symbol-words in the politician's speech makes it possible to construct a speech, addressing not a rational thought but having an influence on the unconscious suggesting stable meanings. With the help of symbols the most vulnerable spheres of consciousness are influenced, which in its turn can trigger strong emotions (fear, anxiety, hope, etc.): "A symbol is an irreplaceable way of integration and mobilisation of groups of people. Symbols are always used where there is a need to express the power of the social union integrity and unity, its collective representation" (Potseluev, 1999, 64).

The psychological trick of the influence of symbols in speech effects the strengthening of unconscious perception and the thoughts of certain individuals and the public in general.

\section{The analysis of the political communication}

Irrespective of the fact that the speech of the player on the political stage is an integral part of the image, the creation of which involves the work of experienced professionals, his/her speech, even a prepared one, unveils the personality beyond the image, the person represents.

As an example let's take the phenomenon of Donald Trump, who was recently widely discussed in political and scientific circles as a person relatively new at the political stage and not used to play a generally accepted political team rules.

What made him so popular and enabled to be elected the president of one of the world's powerful nations?

No doubt, first and foremost, it was a media image cut to meet psychological peculiarities of Mr. Trump himself. An artificially created image of a "new politician" was aimed to influence the psychology of an average American, for whom it is an embodiment of a person, who managed, so to say, "to be self-made": the fact itself inspires confidence and respect making such a person an unchallenged authority. His oral speeches harmoniously combined with his psychological peculiarities were not the last to add to the popularity of his image.

To analyse the psychological and linguistic aspects of the oral speech of president D. Trump we would like to highlight important constituents of his popular media image. As an example we took an extract of the interview with Donald Trump (then the candidate for presidency) in a popular talk show. Let's analyse the answer to just one question.

Jimmy Kimmel: "Isn't it wrong to discriminate based on religion?" (The question referred to the ban to visit the USA for the citizens of Muslim countries).

The answer serving a bright example of the speech specifics of the candidate for presidency was thrust into the spotlight of the public at large judging by the number of views and comments:

"But, Jimmy, the problem - I mean, look, I'm for it. But look, we have people coming into our country that are looking to do tremendous harm. You look at the two - look at Paris. Look at what happened in Paris. I mean, these people, they did not come from Sweden, okay? Look at what happened in Paris. Look at what happened last week in California, with, you know, 14 people dead. Other people going to die, they're so badly injured. And what I wanna do is find out what it - you know, you can't solve a problem until you find out what's the root cause. And I wanna find out, what is the problem, what's going on. And, it's temporary. I've had so many people call me and say thank you. Now, if you remember, when I did that a week ago it was like bedlam. All of a sudden - and you watch last night, and you see people talking. They said, "Well, Trump has a point. We have to get down to the problem." The people that are friends of mine that called to say, "Donald, you have done us a tremendous service." Because we do have a problem, and we have to find out what is the ..." (TPM LIVEWIRE, 2015.12.17).

We applied in our study a complex approach, which presupposes a combination of the means of linguistics and psychology. In the result we obtained an analysis of psychological and linguistic aspects, which makes it possible to realise why his speech is convincing to the public.

1. Donald Trump emphasises the issues of terror and aggression which now worry the world as never before. He addresses to inherent fears of the Americans manipulating their notion about the stereotype of a terrorist as a person from a Muslim country. The image of a terrorist as a representative of a Muslim religion has been cultivated in the Hollywood movies from the beginning of the 70-s of the previous century and was additionally strengthened by the events of the $11^{\text {th }}$ of September 2001. (Thomas Riegler, 2010). As we can 
observe, he turned a simple semantic unit, a name word "Muslim", to the symbol of terrorism carrying a threat to the American society. Additionally, to increase the influence on the emotional constituent, his answer contains the facts of terror attacks in Paris.

2. The usage of short, simple sentences, pauses and stresses on the key word "problem", which is recurrent during the whole answer but in different context: "We have a real problem... can't solve a problem... have to get down to problem...do have a problem" strengthened by a persistent repetition of the word "tremendous" in the context of threat along with "harm", "hatred" in the context of terror attacks that recently took place in Paris (in the sense that the like is possible in this country) increases the feeling of worry for own security.

3. The usage of adjectives "tremendous", "badly" and "dead" to strengthen the meaning of the symbolword result in the evoking of the feeling of worry and creation of the image of a "Messiah", i.e. of a person able to solve quickly and efficiently the problem of terrorism.

4. The usage of a speech algorithm "in case... then...", where the implied meaning expresses the idea: "In case you vote for me, I shall ensure security for you and your children". In this way, Mr. Trump attempts to influence the instinct of self-preservation of each particular recipient.

5. Based on the semantic differential method, we would like to say that the text of the speech of Mr. Trump contains such factors as: the assessment of the situation as bad, the factor of worry as high, the factor of threat of force as strong, the activity factor as high (Trump's activity is aimed at overcoming the problems).

As a conclusion we may say that the success of a public speech of Donald Trump is based on techniques the success of which depends on the using semantic units in the symbol function:

- provoking the feeling of worry via the finality of an utterance;

- addressing the person's inherent fears;

- turning the name word into a symbol-word of terrorism;

- narrowing of the meaning of the notion "security" to one of its semantic variants, namely, "personal security".

Thus, his answer sounds convincing and axiomatically and results in an imposing (suggesting) text, the analysis of which makes it clear, which psychological and linguistic techniques were applied by the $45^{\text {th }}$ president of the USA in his pre-election campaign.

The publicity and communication with an audience is an integral part of political competition, which became extremely sharp during the political race. The players on the political stage do not just represent themselves and their political agenda, they search for support and warrant for their actions in the public's eyes, representing fears, hopes and constructing myths. A symbol is a part of a myth enabling to consolidate the society, to motivate it to combined actions. According to Potseluev (1999), the political communication exploits an essence of a symbol as an image construction, which can contain any spheres of existence giving it the sense of boundless phenomena (p.63).

In our opinion, the speech symbols help to create an idea about the unity of the rulers with the citizens encouraging them to become a part of the majority. This makes it easier for the political elite to control the public opinion by creating the symbols that are aimed at a certain political goal: to decrease or to increase tension, to focus the attention on the "national pride", etc. For example, through building the image of an enemy, a guilty one ("terrorists", "immigrants") or Messiah, the survivor (a certain political force). The symbol words are also certain markers to differentiate between "friend" and "foe". The strategy "friend" or "foe" is also used to justify such actions (for example, the ban of emigration or entrance for the citizens from Muslim countries). A semantic analysis of the text of the speech by Donald Trump in Congress enables us to clearly divide the symbol words marking a semantic field "friend": "the Americans" (mentioned 30 times), "citizens" (mentioned 10 times), "the USA" (mentioned 11 times), "America" (mentioned 30 times), "friend" (mentioned 9 times), "nation" (mentioned 22 times), "every American child" (mentioned 3), etc. To the semantic field "insiders" we also refer semantic units that symbolise the idea of unity of the rulers with the citizens "our" (mentioned 109 times), "all" (mentioned 10 times), "our country" (mentioned 9 times), "community" (mentioned 6 times), "all Americans" (mentioned 4 times), "for Americans" (mentioned 4 times), "for our country" (mentioned 4 times), "across our nation" (mentioned 3 times), etc. The semantic units "immigrant" (mentioned 8 times), "criminal" (mentioned 3 times), "enemy" (mentioned 3 times), "other countries" (mentioned 3 times), "terrorism" (mentioned 3 times) refer to the field symbolising "foe".

The symbol-words that are constructed in the political discourse are capable of turning into objective effective elements of everyday life. They are directly involved in the process of consolidation of the majority with the same idea: "Political discourse is a simplified form of ideology and the means of communication between the rulers and the subordinates" (Gill, 2011, p. 3). 


\section{Conclusions}

Based on the analysis of four aspects in the political speech of Donald Trump, we demonstrated how the application of symbol-words increases the efficiency of the influence on the listener. The mentioned aspects include: conceptual importance of the text or expression of the ideas meeting the expectations of the society; distinctive character of the text ensuring a unique nature and recognisability of the speaker; emotional influence on the public; and encouragement and consent or the "boa Kaa" tactics.

By singling out five criteria of a symbol, which distinguish it from the rest of semantic units, we defined the functions of the symbol-word in the political speech: the function of accentuation; the function of emotional involvement; and the function of narrowing of the symbol-word semantic field.

Thus, the analysis of the products of political communication demonstrated that the words of the text, when respectively applied in the functions of various semantic units, define the efficiency of the speech and help to influence the public (listener) through highlighting the accents and involving an emotional constituent. The research allows to analyse the intentions of the speaker and identify the primary intention of the speech. The results can be used for the analysis of verbal communication and written text in the sphere of politics.

The perspective of research lies in further studying of political communication, applying the intent and content analysis of text for identification the techniques of psychological influence on peoples' consciousness.

\section{References:}

Bird, P. (1999). Sell yourself. Persuasive tactics to boost your image. London: Groom Helm.

Edelman, M. (1990). Politik als Ritual: die symbolische Funktion staatlicher Institutionen und politischen Handelns. Frankfurt am Main; New York: Campus Verlag.

Gill, G.J. (2011). Symbols and legitimacy in Soviet politics. New York: Cambridge University Press.

Ivanov, V. F. (2004). Sociologichni aspekti metodologiï ta modeli masovoï komunikaciï [Sociological aspects of methodology and models of mass communication]. Naukovi zapiski. Fakul'tet sociologii ta psihologiï. Institut zhurnalistiki, V, 121-132. https://doi.org/10.1017/cbo9780511791437

Jung, K.G. (2015). Arhetip i simvol [Archetypes and Symbols]. Nizhny Novgorod, Russia: Kanon pljus.

Jung, K.G. (2016). Chelovek i ego simvoly [Man and His Symbols]. St.P, Russia: Medkov.

Krylova-Grek, Yu.M. (2007). Psykholinhvistychni osoblyvosti perekladu semantychnykh odynyts [The psycholinguistic peculiarityes of translation of semantic units] (Unpublished PhD dissertation). G.S. Kostyuk Institute of Psychology of the National Academy of Pedagogical Sciences (NAPS) of Ukraine, Kyiv.

Losev, A.F. (2014). Problema simvola i realisticheskoe iskusstvo [The problem of symbol and realistic art]. Moscow, Russia: Russkij Mir.

Malinova, O. Ju.(2015). Mif kak kategorija simvolicheskoj politiki: analiz teoreticheskih razvilok [Myth as a category of symbolic politics: analysis of theoretical forks]. Polis. Politicheskiye issledovaniya, 4, 12-21. https://doi.org/10.17976/jpps/2015.04.03

Malinova, O.Ju. (2013). Konstruirovanie smyslov: Issledovanie simvolicheskoj politiki v sovremennoj Rossii [The construction of meanings: The study of symbolic politics in modern Russia]. Moscow, Russia: RAN. INION.

Meyer, T. (1994). Die Transformation des Politischen. Frankfurt am Main: Suhrkamp.

Nahorna, L.P. (2005). Politychna mova i movna polityka: diapazon mozhlyvostey politychnoyi linhvistyky [Political speech and language policy: the range of possibilities of political linguistics]. Kyiv, Ukraine: Svitohlyad.

Pocheptsov, G.G. (2006). Imidzheologija [Image Studies]. Moscow, Russia: Refl-buk, Vaklerb.

Pocheptsov, G.G. (2015). Informacionnye vojny. Novyj instrumentarij politiki [Information war. The new policy tools]. Moscow, Russia: Algoritm.

Potseluev, S.P. (2014). Fenomen simvolicheskogo dialoga v politike: uslovija vozmozhnosti i rossijskie praktiki [The phenomenon of symbolic dialogue in politics: the conditions of possibility and Russian practice]. Voprosy philosophii, 7, 144-153.

Potseluev, S.P. (1999). Symbolic politics: constellation of concepts for approach to the problem. Polis. Politicheskie issledovanija, 5, $62-75$.

Riegler, T. (2010). Through the Lenses of Hollywood: depictions of Terrorism in American Movies. Journal of the Terrorism Research Initiative and the Center for Terrorism and Security Studies, 4 (2). Retrieved 10.04.2017 from: http://www.terrorismanalysts.com/pt/index.php/pot/article/view/98/html

Sarcinelli, U. (2011). Politische Kommunikation in Deutschland: Medien und Politikvermittlung im demokratischen System. German Edition: VS Verlag.

Shomova, S.A. (2016) Ot misterii do strit-arta. Ocherki ob arhetipah kul'tury v politicheskoj kommunikacii [From mystery to street art. Essays on the archetypes of culture in political communication]. Moscow, Russia: Izd. dom Vysshej shkoly jekonomiki.

Teun, A. van Dijk. (2013). Discurs $i$ vlast. Reprezentacija dominirovanija v jazyke i kommunikacii [Discourse and Power. Representation of dominance in language and communication]. Moscow, Russia: Librokomb.

TPM LIVEWIRE (2015.12.17). Kimmel Presses Trump: “Isn't It Wrong To Discriminate” Based On Religion? [VIDEO]. Retrieved from: http://talkingpointsmemo.com/livewire/jimmy-kimmel-donald-trump-muslim-ban

Levada, Ju. A. (2011). Sochinenija: izbrannoe: sociologicheskie ocherki, 2000-2005. [Compositions: favorites: sociological essays, 2000-2005]. Moscow, Russia: Izdatel "Karpov E.V.".

Donald Trump's Congress speech (full text). (2017, March 1). CNN. Retrieved 27.03.2017 from http://edition.cnn.com/2017/02/28/politics/donald-trump-speech-transcript-full-text/ 